\title{
Musharakah Mutanaqisah Partnership in Malaysia's Islamic Bank: A Comparison Between Theory and Practice
}

\author{
Lee Ching Lung \\ Kulliyyah of Economics and Management Sciences, \\ International Islamic University, Kuala Lumpur, Malaysia
}

Received 2012-08-25; Revised 2012-09-01; Accepted 2014-02-12

\begin{abstract}
Diminishing Musharakah Mutanaqisah Partnership (MMP) contract has been offered by Islamic banks in Malaysia, this study aims to presents the result of a comparison made between the theoretical explanations of how the MMP works and what is actually being done in practice. This study makes use of a qualitative approach in analysing how the MMP works in practice. It then makes a comparison between the MMP as being practiced in real situation and what theoretical writing tells us to expect by analysing an offer letter of a customer of HSBC Amanah Malaysia. Further research is carried out on home financing packages offered by 10 local Islamic banks and 6 foreign Islamic banks by calling the banks and walking into the branches. Our findings reveal that HSBC Amanah Malaysia is using base financing rate replacing the market rental rate of which the base financing rate is the same as base lending rate in the conventional housing loan. In addition, HSBC Amanah also imposes penalty charges on any early settlement and redemption. Other local and foreign banks are also using similar base financing rate to determine the rental rate and only a few of them are not imposing penalty charges on early settlement and redemption. This study provides result that HSBC Amanah's Home Smart-i facility, the MMP in practice is moving towards a convergence to conventional banking and in fact, there is no difference with conventional housing loan. For HSBC Amanah to truly offer and reflect the principles and tenets behind MMP contracts, it has to make some amendments to the terms and conditions as stated in its offer letter for a diminishing musharakah mutanaqisah partnership contract.
\end{abstract}

Keywords: Annual Percentage Rate (APR), Automatic Teller Machine (ATM), Al-Bay Bithaman Ajil (BBA), Bank Negara Malaysia (BNM), Base Financing Rate (BFR), Base Lending Rate (BLR), Islamic Base Rate (IBR), Musharakah Mutanaqisah Partnership (MMP)

\section{INTRODUCTION}

The fundamental essence of Islamic Finance is the avoidance of "Riba" in financial and economic transactions. In achieving this with mortgage financing, there are principally two mostly used methods of home financing amongst others Al-Bay Bi-thaman Ajil (known as BBA) and the Musharakah Mutanaqisah Partnership (known as MMP).

The BBA is a contract for the sale of a house whereby the house is sold immediately (spot) but the payment is deferred over a fixed period of time in instalments. The price is made up of the cost price and the return/profit on the transaction. This essentially implies that it is a murabaha contract (Meera and Razak, 2005). The market interest rate serves as a bench mark for the rate of return on the BBA transaction, hence its (BBA) dependence on the market interest rate. The rate of return is also fixed for the duration of the contract and is determined by the financier i.e., the financial institution. However, due to some practical issues such as no risk taking involved in BBA contracts and the mismatch of long term funds to short term funds, the MMP is a more favoured financing method than the BBA. 
MMP is a contract which is based on a diminishing partnership and considered to be more shariah compliant than the BBA (Meera and Razak, 2005). The customer or client purchase the share of the financier until he purchases all and owns the property. Meanwhile the financier will lease out the property to the client and instalment payments known as rental rates. In doing this, the client promises to purchase the share of the financier and this process illustrates that the MMP is made up of three (3) contracts i.e., partnership, sales and lease (Osmani and Abdullah, 2010).

The periodic rental sum is shared between the client and the financier according to their capital contribution i.e., the percentage holding and this ratio varies with every payment with the customer's ratio increasing with every payment. This continues until the asset is fully owned by the client (Meera and Razak, 2009).

\subsection{Objective of the Study}

Under the MMP principle, rate of return is determined as a percentage of the house rent and is not based on the market interest rate, hence the tendency for the banks to finance properties with high rental rates are higher compare with low rental properties. Therefore, the objective of this study is to examine whether the MMP principles are being adhered to by Islamic banks in Malaysia by comparing the actual MMP contract offered by Islamic banks with the MMP in theory.

The paper is structured into five chapters. Chapter one covers the introduction and objective, chapter two focuses on the literature review, chapter three is on the methodology, chapter four makes a comparison of theory and practice while chapter five concludes the paper.

\section{LITERATURE REVIEW}

According to Al-Harran (1993) with his research title of "Musharakah Financing: Concept, Principles and Financing", he explained the Islamic finance's partnership concept, what types of partnership and also the practices on liability of loss, distribution of profit, withdrawal of members.

A study by Bendjilali and Khan (1995) explained the need and importance of diminishing partnership and also defined the perpetual partnership but they did not explain the features of Musharakah Mutanaqisah Partnership. Haron (1997) also did not explain Musharakah Mutanaqisah Partnership in his book but provides the history, philosophy, rules of Islamic banking and explained the types of Islamic financial products.
Pakistan Islamic bank like Meezan Bank has been implementing Musharakah Mutanaqisah Partnership for house financing for quite some time. Usmani (2002) has explained the operational method of house financing in Meezan Bank and also the Musharakah Mutanaqisah Partnership's characteristics in Pakistan's Islamic banks. Usmani (2005) also explained the Musharakah Mutanaqisah Partnership contract not only in the home financing but also in the trade and business services with Shariah principles in place.

Al-Bay' Bi-thaman Ajil (BBA) was once a very popular method of home financing in Malaysia before the introduction of Musharakah Mutanaqisah Partnership by Islamic banks in Malaysia. In the study done by Meera and Razak (2005), they compared the home financing package between BBA and MMP and they concluded that MMP home financing is a better alternative compare to BBA home financing. They argued that the profit rate of BBA is fixed and it also follows the similar computation in the interest based system.

Razak (2006) in the National Seminar on BBA Home Financing, has defined what is BBA home financing, how it operates, how to determine the selling price, legal documentation and also some issues faced in BBA home financing.

Smolo (2007) in his thesis with the title of "A Theoretical Comparison between Al-Bay'Bi-thaman Ajil (BBA), Musharakah Mutanaqisah Partnership (MMP) and Ijarah Sukuk" has explained and compare the theoretical concept between the three.

Another comparison between BBA and MMP home financing was done by Nor (2008), she also concluded that MMP home financing is a better alternative as compare to BBA home financing as MMP is fair to the customers. She also compares the structures of BBA and MMP, the problems and risks faced in practicing the contracts and also their acceptance in the Shariah.

Meera and Razak (2009) further explained the issues encountered in practising MMP contract. They found out that the banks are replacing the rental rate with market interest rate of which interest should be avoided in real Islamic banking and the rental rate supposed to be determined by the market rental of the property divided by the value of property.

A more recent study was done by Osmani and Abdullah (2010) on Musharakah Mutanaqisah home financing, they reviewed the practices Islamic Banks in Malaysia. They mentioned that many Islamic banks in Malaysia today accept Musharakah Mutanaqisah home financing as an alternative to BBA. Their study also 
adopts qualitative method to analyze the existing practices of Islamic banks and to see critically if it conforms to the strict principles of Shariah.

\subsection{Bank Negara Guideline}

The guidelines of the Musharakah Mutanaqisah Partnership contracts for the Islamic Banks as given by Bank Negara must have the following objectives:

- To improve corporate governance activity in order to manage the MMP contract for Islamic institutions

- To improve upon and mitigate the management of risks of the MMP contract

- To diversify the Islamic banking risk into equitybase or floating-rate

- To serve as an assessment tool for Islamic banking institutions

\subsubsection{Basics Tenets for Musharakah Mutanaqisah Contracts}

- Both partners can contribute the capital, but the capital need not be equal i.e., one party can contribute more than the other

- Both parties must act for the management of the business, if one party wants to act as a sleeping partner, it must choose a third party to act on its' behalf

- The business that is being undertaken must be allowed by shariah

- The portion of the profit must be agreed upon between the partners at the beginning of the contract

- Any loss must be shared between the partners according to their capital contribution ratio, but if the loss occurs as a result of the negligence of the management team, such losses shall be borne by the management team

\subsection{MMP Theoretical Background}

Musharakah Mutanaqisah also known as diminishing partnership which is an Islamic method of home or property financing whereby an Islamic Bank and the customer jointly owns the property (Meera and Razak, 2005) and the Islamic Bank leases its share/ownership of the property to the customer in the form of ijarah (lease).

The customer promises to redeem/purchase the Islamic Bank's ownership share of the asset until the whole property becomes the customer's. The customer pays to the Islamic Bank, a monthly rental which serves to redeem the Bank's share of the property. At the end of the lease period the customer becomes the sole owner of the property after he has purchased all the ownership ratio of the Bank.

\subsection{Process of Musharakah Mutanaqisah Partnership Contract}

- Both customer and Islamic bank contribute the capital for the acquisition of the house/property

- The Islamic bank leases the asset to the customer

- Partner/customer pays the rent. (Rent increases the ownership of the customer/partner)

- Islamic Bank transfers ownership of the asset to the partner/customer

\subsection{MMP Rental Formula}

The MMP uses the same formula as conventional Banks to calculate the monthly payment but MMP replaces the interest rate with the rental rate (Meera and Razak, 2005) and it is calculated as:

$$
\text { The rental rate, } \mathrm{x}=\mathrm{X} / \mathrm{P}
$$

Where:

$\mathrm{X}=$ Monthly rental payment

$\mathrm{P}=$ Total value of the asset

The formula that conventional Banks use is as follows:

$$
\mathrm{PV}=\mathrm{Pmt} / \mathrm{i}\left[1-1 /(1+\mathrm{i})^{\mathrm{n}}\right]
$$

Rearranging and making Pmt the subject, the formula become as follows:

$$
P m t=i(1+i)^{n} P V /(1+i)^{n}-1
$$

Where:

$\mathrm{PV}=$ Present value of the loan

Pmt $=$ Monthly Payment

$\mathrm{i}=$ Interest rate paid periodically

$\mathrm{n} \quad=$ number of the period

In order to get the MMP formula, we replace the interest rate (i) with the rental rate (x), thus, we get MMP formula as follows:

$$
\mathrm{M}=\mathrm{x}(1+\mathrm{x})^{\mathrm{n}} \mathrm{B} /(1+\mathrm{x})^{\mathrm{n}}-1
$$

Where:

$\mathrm{M}=$ Periodically payment to the bank (include the additional amount of rental) 
$\mathrm{x}=$ Rental rate periodically

$\mathrm{n}=$ Number of periods

$\mathrm{B}=$ Initial bank share

The customer makes periodic payment to the Bank which includes the additional amount of rent that will be used to redeem the Bank's share gradually. Example is if the rental is RM2,000, but the customer pays RM2,500, RM500 is the additional amount that can be used to redeem the bank's share until the customer owns $100 \%$ of the asset.

The formula that is used to find the additional amount is as follows:

$$
A=\frac{x\left[P-(1+x)^{n} C_{0}\right]}{(1+x)^{n}-1}
$$

Where:

$\mathrm{A}=$ Additional amount that customer needed to pay in order to increase its ownership.

$\mathrm{X}=$ Rental rate

$\mathrm{P}=$ Total value of the asset

$\mathrm{C}_{\mathrm{O}}=$ Contribution of the customer to purchase of the asset

$\mathrm{n}=$ Number of period all formulas taken from (Meera and Razak, 2005)

\section{Example of MMP Calculation}

Price of house

$=$ RM 300,000

Initial contribution of customer $=\mathrm{RM} \mathrm{60,000}$

Initial contribution of financier $=\mathrm{RM} 240,000$

Monthly rent

$=\mathrm{RM} 2,000$,

Number of years

$=12$ years

In order to redeem the financier's share within 12 years, the customer has to pay on top of monthly rental of 2,000 as calculated below:

$$
A=\frac{x\left[P-(1+x)^{n} C_{o}\right]}{(1+x)^{n}-1}
$$

Where:

$$
\begin{aligned}
& \mathrm{x}=\frac{\text { monthly rental }}{\text { house price }} \\
& =0.667 \% \text { per month } \\
& \mathrm{A}=\frac{0.00667\left[300,000-(1+0.00667)^{144} * 60,000\right]}{(1.00667)^{144}-1} \\
& \mathrm{~A}=\text { RM } 597.41
\end{aligned}
$$

There the additional amount the customer has to pay is RM 597.41:

Alternatively

Balance $=\operatorname{Pmt} / \mathrm{x}\left[1-\left(1 /(1+\mathrm{x})^{\mathrm{n}}\right)\right]$

$240,000=\mathrm{Pmt} / 0.00667\left[1-\left(1 /(1.00667)^{144}\right)\right]$

$\mathrm{Pmt}=2,598.41$

The additional amount is RM2,598.41-RM2,000

$=$ RM 598.41

The customer's ownership ratio after 6 years (i.e., after the 72 nd payment):

Balance of financial equity $=\operatorname{Pmt} / \mathrm{x}\left[1-\left(1 /(1+\mathrm{x})^{\mathrm{n}}\right)\right]$

Balance of financial equity

$=2,598.41 / 0.00667\left[1-\left(1 /(1.00667)^{72}\right)\right]$

Balance of financial equity $=$ RM 148,182.57

Balance of customer $=$ RM300,000-RM148,182.57

$=\mathrm{RM} 151,817.43$

Customer ownership ratio

$=\mathrm{RM} 151,817.43 / \mathrm{RM} 300,000=0.5061$

\section{METHODLOGY}

This study makes use of a qualitative approach in analysing how the MMP works in practice. It then makes a comparison between the MMP as being practiced in real situation and what theoretical writing tells us to expect by analysing an offer letter of a customer of HSBC Amanah Malaysia Berhad.

Further research is carried out on home financing packages offered by other local and foreign Islamic banks. A total numbers of 16 Islamic banks consisting of 10 local Islamic banks and 6 foreign Islamic banks were selected from the member list of Association of Islamic Banking Institutions Malaysia. On the research on other banks, only the rental rate, the name of bank's home financing package, what types of shariah concept, the maximum margin and age of financing were included.

\subsection{Musharakah Mutanaqisah Partnership (MMP) Contracts in Practice by HSBC Amanah}

For Musharakah Mutanaqisah Partnership (MMP) Contracts in practice, we will explain in details the MMP home financing package offered by HSBC Amanah Malaysia Berhad. HSBC Amanah named their MMP Contracts as Diminishing Musyarakah Mutanaqisah HomeSmart-i Facility or in short, HomeSmart-i. 


\subsection{Monthly Rental or Leased Rental Rate of Homesmart-I}

In practice by HSBC Amanah, the monthly rental is called Leased Rental Rate and the leased rental rate is based on the bank's Base Financing Rate (BFR) of which the Base Financing Rate for this case is $6.05 \%$ per annum in June 2010. The Base Financing Rate is also subject to fluctuations at the bank's discretion. The Base Financing Rate which was fixed by HSBC Amanah is actually the same as conventional housing loan's Base Lending Rate (BLR).

Due to competition of banks to attract borrowers to borrow money, a lot of banks have offered leased rental rate below the Base Financing Rate i.e., Base Financing Rate minus spread. The spread amount differs from bank to bank and also depends on the loan amount. If the loan amount is large, the minus spread will be higher and vice versa if the loan amount is small, then the minus spread will be smaller.

In this case of MMP contract offered by HSBC Amanah, the leased rental rate is Base Financing Rate minus $1.95 \%$ on daily rest, therefore the leased rental rate as charged by HSBC Amanah is Base Financing Rate of 6.05\% (@30 $30^{\text {th }}$ June 2010) minus the spread of $1.95 \%$ which was equal to $4.1 \%$ per annum:

Leased Rental Rate $=$ Base Financing Rate-spread

$=6.05-1.95 \%$

$=4.1 \%$ per annum

\subsection{Facility Tenure}

HSBC Amanah allows facility tenure with minimum 10 years and maximum 35 years or until the age of 65 , whichever is earlier. In practice by HSBC Amanah, they always try to give longer tenure instead of shorter tenure if the borrower is eligible.

For example in this case:

The age of the borrower $=38$ years old

The tenure granted was 27 years $=324$ months

Thus, HSBC Amanah offers the customer until the age of 65 years old $(38+27)$.

\subsection{Facility Amount and Equity}

The facility or financing amount offered by banks in Malaysia depends on the borrowers' income. The rule of thumb is; the monthly repayment should not exceed one third of the borrower' monthly income. This is a refinancing case and it is not a new financing to buy property from developer:
From the offer letter

Market value of the property $\quad$ RM320,000

HSBC granted facility amount of RM180,000

Which includes legal and valuation fees of RM5,993 and customer to bear the legal and valuation fees.

\subsection{Monthly Payment}

To calculate the monthly payment under MMP by HSBC Amanah, it is actually the same calculation as conventional housing loan as HSBC has charged the leased rental rate based on Base Financing Rate of which the Base Financing Rate is the same as conventional Base Lending Rate (Table 1).

From the above case:

Financier provide (Present value or $\mathrm{B}_{0}$ )

$=\mathrm{RM} 180,000$

Tenure $(\mathrm{n})=27$ years or 324 months

Leased Rental Rate (i or $x$ ) $=4.1 \%$ per annum or $0.342 \%$ per month

Using the financial calculator,

Therefore monthly payment $(\mathrm{PMT}$ or $\mathrm{M})=\mathrm{RM} 919.52$

The monthly payments are also subject to adjustment if there is any variation in the leased rental rate as a result of changes in the Base Financing Rate (BFR). If $\mathrm{BFR}$ increases, leased rental rate will increase and the monthly payment will increase and vice versa.

\subsection{Other Features of HSBC Amanah Homesmart-I}

- Freedom to make prepayments anytime without notice or charges

- Consolidate all the deposits including salary, savings and bonus into one HomeSmart-i account

- Reduce the total amount of payment and significantly shorten the financing tenure

- Freedom to make withdrawals on excess payments anytime without notice or charges

- Banking convenience via Automatic Teller Machine (ATM), cheque book with a monthly service fee of RM10 and Internet banking

- $20 \%$ stamp duty waiver on financing documents on new home purchases

- Stamp duty waiver for refinancing from the existing conventional home loan to HomeSmart-i. (on redemption amount only) 
Table 1. Calculation of Financier and Customer's Equity

\begin{tabular}{llll}
\hline Financier's Equity & Customer's Equity & Total & RM325,933.00 \\
\hline Initial Capital Contribution & RM180,000.00 & $\begin{array}{l}\text { RM145,993.00 (Including legal } \\
\text { and valuation fees of RM5,993) }\end{array}$ & $100 \%$ \\
Percentage or ratio in the MMP & 55.22 or $0.5522 \%$ & $44.78 \%$ or 0.4478 & \\
\hline
\end{tabular}

\subsection{Additional Conditions Imposed By HSBC}

- A monthly service fee of RM10 will be debited to the account of the customer from the date of first drawdown

- Customer bear the legal and valuation fees which includes in the facility amount

- If early settlement of the facility within 60 months from the first drawdown, there is early settlement charges of $3 \%$ of the full facility amount or RM5000 whichever is higher

- For failure to pay the monthly payment within the time allowed, compensation rate of $1 \%$ per annum is charged to the outstanding monthly payment and the amount of compensation shall not be compounded

- The customer is also responsible for all the maintenance and repair of the property under the Property Ijarah Agreement

\section{COMPARISON OF MMP CONTRACTS BETWEEN THEORY AND PRACTICE}

To compare MMP contracts between theory and practice, I first will do the simulation according to MMP in theory by calculating the market rental rate, repayment per month and the financier's profit. Then, I will use the figure to compare the MMP Home Smart-i offered by HSBC Amanah Malaysia.

\subsection{Simulation of MMP in Theory against MMP in Practice}

As this application is a refinancing case, HSBC Amanah has asked the property valuer to do a valuation on the house and the property valuer has valued the house and worth RM320,000:

Current value of house $\quad=$ RM320,000

(Purchase price from developer $=$ RM260,000; 23.1\% appreciation in the house value)

Based on HSBC Amanah's offer letter:
HSBC Amanah provides
$=\mathrm{RM} 180,000$
Number of repayment, $n$
$=324$ months or 27 years
The market monthly rental of the house $=$ RM1000

According to MMP Theory,

Rental rate $=$ Rental/Value of property

$=\mathrm{RM} 1000 / \mathrm{RM} 320,000$

$=0.3125 \%$ per month or $3.75 \%$ per year

Using the formula or financial calculator, the monthly payment is RM884.27 for MMP in theory as compare to MMP Home Smart-i repayment of RM919.52 per month. There is an extra repayment of RM35.25 (RM919.52RM884.27) for HSBC Amanah Home Smart-I facility.

The total payment in 27 years for MMP in theory is RM286,503.48 (RM884.27 $\times 12$ months $\times 27$ years) while the total payment in 27 years for MMP in practice by HSBC Amanah is RM297,924.48 (RM919.52 x 12 months $\mathrm{x} 27$ years). There is also an extra total payment of RM11,421 (RM297,924.48-RM286,503.48) for HSBC Amanah Home Smart-i facility as compare to MMP in theory which is using the rental rate.

Therefore, the profit to HSBC Amanah is RM117,924.48 (RM297,924.48-RM180,000) while the profit to the bank if under the MMP theory is RM106,503.48 (RM286,503.48-RM180,000). HSBC Amanah's profit amount is also higher by RM11,421 of which it is the same amount as the extra total payment to the bank.

A summary of rental rate, monthly repayment, total repayment and total profit to the bank for both HSBC Amanah Home Smart-i and MMP in theory are as followings.

From the calculation as per Table 2, it is observed that HSBC Amanah is not using the MMP theoretical rental rate but instead, using Base Financing Rate which is the same rate as Base Lending Rate. The bank has substituted the rental rate with the market interest rate. The reason for this substitution is that the bank's cost of funds is tied to the market interest rate, the market interest rate is usually higher than the rental rate and the bank also does not need to determine the rentals of which different locations have different rentals price.

As HSBC Amanah is using Base Financing Rate instead of market rental rate, therefore the Annual Percentage Rate (APR) is higher at $4.1 \%$ per annum as compare to market rental rate of $3.75 \%$ per annum. Thus, the monthly repayment and total repayment as well as profit to the bank are higher than MMP in theory. 
Table 2. Summary of Calculation for MMP in Theory and in Practice by HSBC Amanah

\begin{tabular}{llll}
\hline $\begin{array}{l}\text { Price of house } \\
=\text { RM320K }\end{array}$ & $\begin{array}{l}\text { HSBC Amanah provide } \\
\text { = RM180K } \\
\text { MMP in practice by HSBC Amanah }\end{array}$ & $\begin{array}{l}\text { Monthly Rental } \\
=\text { RM1000 } \\
\text { MMP in theory }\end{array}$ & Variance \\
\hline BFR / Rental rate & $4.1 \%$ per annum & $\begin{array}{l}(\text { RM1000/RM320,000 }) \times 12 \\
=3.75 \% \text { per annum }\end{array}$ & Extra 0.35\% per annum \\
& & RM884.27 & RM35.25 \\
Monthly payment & RM919.52 & RM286,503.48 & RM11,421 \\
Total payment in 27 years & RM297,924.48 & RM106,503.48 & RM11,421 \\
Total Profit to Bank & RM117,924.48 & & \\
\hline
\end{tabular}

On the degree of rental rate in MMP in theory, the rental rate is fixed for entire tenure or fixed for different phases specifically agreed upon. While HSBC Amanah Home Smart-i base financing rate is subject to fluctuation at the bank's discretion normally depends on the market Base Lending Rate.

The market rental rate is not always in the upward trends. When there is economic downturn, the market rental rate for MMP in theory will be reduced while the bank still base on floating market interest rate which is always higher than their cost of fund as the bank does not want to take any risk.

In theory, MMP is considered a joint ownership agreement, therefore the legal fee is lower but in practice, the legal fee is higher as HSBC Amanah imposed more documents and procedures such as Facility agreement, legal charge on the property, property ijarah agreement.

For MMP in theory in the case of customer's default of which he or she cannot repay the monthly payment, the property needs to be revaluated and sell in the auction at market price and the proceeds will be shared according to ownership ratio between the financier and customer after deducting the liquidation cost.

Whereas for the case of Home Smart-i, HSBC Amanah's Personal Financial Services Account Manager, Ms Lina Caniago informed that if customer defaulted, the customer needs to pay the remaining balance on the Bank's share and customer also bears the cost of transfer and the Bank will exercise the power of attorney to sell the property to a third party. The bank will keep all the proceeds after deducting all the outstanding financing amount, rental arrears and liquidation cost which is contradicting with the MMP principles.

In case of early settlement of the facility within 60 months, HSBC Amanah is charging early settlement charges of $3 \%$ of the full amount facility or RM5000 whichever is higher. Whereas for MMP in theory, there is no early settlement charges.
The summary on major differences between MMP Contracts in theory and practice as shown in the case of HSBC Amanah are as Table 3.

\subsection{Comparison of HSBC Amanah's Current Home Financing Rate and before}

The above comparison between MMP in theory and MMP in practice by HSBC Amanah was based on the home financing offer letter dated 30th June 2010. The base financing rate might have changed now due to the bank's cost of fund.

According to the home page of HSBC Amanah Malaysia, the current base financing rate is $6.6 \%$ as at 27 th December 2011. There is an increase rate of $0.45 \%$ as compare to the base financing rate of $6.05 \%$ as at the home financing offered at 30th June 2010.

Whereas the spread from base financing rate is now minus $2.1 \%$ offered by HSBC Amanah as compare with the lower spread of minus $1.95 \%$ in June 2010. Therefore, the net leased rental rate is as follows:

As at $30^{\text {th }}$ June 2010 , leased rental rate

$=$ BFR-spread

$=6.05-1.95 \%=4.1 \%$

As at 27 th December 2011, leased rental rate

$=6.60-2.10 \%=4.5 \%$

Although the spread has been increased from minus $1.95 \%$ to minus $2.10 \%$, the leased rental rate still has a net increase of $0.40 \%$ due to the increase of base financing rate from 6.05 to $6.60 \%$. The calculation of the percentage increase of leased rental rate is as follows:

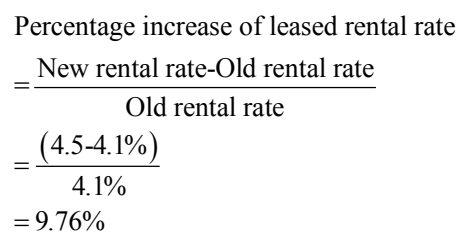


Table 3. Comparison between MMP in theory and practice by HSBC Amanah

\begin{tabular}{|c|c|c|}
\hline MMP & In theory & Home Smart-i by HSBC Amanah \\
\hline Calculation of Rental Rate & $\begin{array}{l}\text { Based on Monthly rental divided by } \\
\text { Price of property } \\
=\mathrm{RM} 1000 / \mathrm{RM} 320,000 \\
=0.3125 \% \text { per month }\end{array}$ & $\begin{array}{l}\text { Base Financing Rate (which is the same as } \\
\text { the conventional Base Lending Rate, usually } \\
\text { higher than the rental rate) } \\
=\text { BFR-spread }=6.05-1.95 \% \\
=4.1 \% \text { per year }=0.3417 \% \text { per month }\end{array}$ \\
\hline Annual \% Rate (APR) & $\begin{array}{l}\text { Lower if based on market rental rate } \\
=0.3125 \% \times 12=3.75 \% \text { per year }\end{array}$ & $\begin{array}{l}\text { Higher as it based on market interest rate } \\
=0.3417 \% \times 12=4.1 \% \text { per year }\end{array}$ \\
\hline Monthly payment & $\begin{array}{l}\text { Lower due to lower APR } \\
=\text { RM884.27 per month }\end{array}$ & $\begin{array}{l}\text { Higher due to higher APR } \\
=\text { RM919.52 per month }\end{array}$ \\
\hline Total Profit to the bank & $\begin{array}{l}\text { Lower due to lower APR } \\
=(\mathrm{RM} 884.27 \times 12 \times 27)-\mathrm{RM} 180 \mathrm{~K} \\
=\mathrm{RM} 106,503.48\end{array}$ & $\begin{array}{l}\text { Higher due to higher APR } \\
=(\mathrm{RM} 919.52 \times 12 \times 27)-\mathrm{RM} 180 \mathrm{~K} \\
=\mathrm{RM} 117,924.48\end{array}$ \\
\hline The Degree of Rental Rate & $\begin{array}{l}\text { Fixed for entire tenure or different phases } \\
\text { specifically agreed upon. }\end{array}$ & $\begin{array}{l}\text { Subject to fluctuation at the bank's discretion } \\
\text { normally depends on the market interest rate. }\end{array}$ \\
\hline Fluctuation of Market's rental & $\begin{array}{l}\text { The market rental may depreciate due to } \\
\text { economic downturn }\end{array}$ & $\begin{array}{l}\text { The bank does not want to take risk, just } \\
\text { based on the floating market interest rate } \\
\text { is always higher than their cost of fund. }\end{array}$ \\
\hline Legal Fee & Lower as it is a Joint Ownership Agreement & $\begin{array}{l}\text { Higher as more documents are needed by the } \\
\text { bank such as Facility agreement, legal charge } \\
\text { to the property, property ijarah agreement. }\end{array}$ \\
\hline $\begin{array}{l}\text { Transfer of shares or } \\
\text { Early settlement }\end{array}$ & No early settlement charges & $\begin{array}{l}3 \% \text { early settlement charges of full facility } \\
\text { amount. }\end{array}$ \\
\hline Location of property & $\begin{array}{l}\text { Different location, different rental rate. } \\
\text { Some location may have lower rental rate. }\end{array}$ & $\begin{array}{l}\text { Any location, same Base Financing Rate. } \\
\text { Customer needs to pay the remaining }\end{array}$ \\
\hline In case of default & $\begin{array}{l}\text { Property needs to be revaluated and sell in } \\
\text { the auction at market price and the proceeds } \\
\text { shared according to ownership ratio between } \\
\text { financier and customer after deducting the } \\
\text { liquidation cost. }\end{array}$ & $\begin{array}{l}\text { balance on the Bank's share and customer } \\
\text { also bears the cost of transfer and the } \\
\text { Bank will exercise the power of attorney } \\
\text { to sell the property to a third party. The } \\
\text { bank will keep all the proceeds after } \\
\text { deducting all the outstanding financing } \\
\text { amount, rental arrears and liquidation cost. }\end{array}$ \\
\hline
\end{tabular}

The leased rental rate charged by HSBC Amanah Malaysia has increased $9.76 \%$ for just 18 months from June 2010 to December 2011. If the bank were adhered to MMP principle to calculate the rental rate, the leased rental rate is at least will be fixed for a period of time according to Joint Ownership Agreement.

\subsection{Islamic Home Financing By Other Banks}

Further research was carried out to determine whether other local and foreign Islamic banks in Malaysia are adhering to the MMP principles. The research will cover a total numbers of 16 Islamic banks in Malaysia which are offering Islamic home financing package of which 10 are local Islamic banks and 6 are foreign Islamic banks.

The local Islamic banks are Affin Islamic Bank, Alliance Islamic Bank, AmIslamic Bank, Bank Islam Malaysia, Bank Muamalat Malaysia, CIMB Islamic Bank, Hong Leong Islamic Bank which has acquired EONCAP Islamic Bank, Maybank Islamic, Public Islamic Bank and RHB Islamic Bank.
Whereas the foreign banks which offer Islamic home financing are Al Rajhi Bank, Asian Finance Bank, HSBC Amanah Malaysia, Kuwait Finance House, OCBC AlAmin and Standard Chartered Saadiq.

A lot of these foreign banks have been aggressively opening up new Islamic bank branches all over Malaysia although they are not originally from Islamic country. For example, HSBC Bank, OCBC Bank and Standard Chartered Bank have been opening more and more Islamic bank branches. The reason behind of this new venture is the potential growth of Islamic banking in Malaysia.

The research on other Islamic banks that offer Islamic home financing were done through 16 calls to the home financing department and also 4 numbers of walking in to the bank branches. It was pretended that I wanted to refinance my property for the financing amount of RM200,000 although the HSBC Amanah's Home Smart-i home financing lock in period of 5 years is not due yet. 
Table 4. Summary of Islamic Home Financing Package by Local Banks

\begin{tabular}{|c|c|c|c|c|c|c|}
\hline Local Bank & $\begin{array}{l}\text { Name of } \\
\text { Home Fin. }\end{array}$ & $\begin{array}{l}\text { Rental Rate } \\
\text { (a) 27.12.11 }\end{array}$ & $\begin{array}{l}\text { Shariah } \\
\text { Concept }\end{array}$ & $\begin{array}{l}\text { Mar. of } \\
\text { Fin. }\end{array}$ & $\begin{array}{l}\text { Max } \\
\text { Age }\end{array}$ & $\begin{array}{l}\text { Lock in period and } \\
\text { early settle penalty }\end{array}$ \\
\hline $\begin{array}{l}\text { Affin Islamic } \\
\text { Bank }\end{array}$ & Home Fin.-i & BFR-2.1\% & BBA & $95 \%$ & 75 & Yes \\
\hline $\begin{array}{l}\text { Alliance Islamic } \\
\text { Bank }\end{array}$ & $\begin{array}{l}\text { i-Wish Home } \\
\text { Fin.-i }\end{array}$ & BFR-2.1\% & BBA & $95 \%$ & 70 & Yes \\
\hline $\begin{array}{l}\text { Am- Islamic } \\
\text { Bank }\end{array}$ & Home Fin.-i & BFR-2.0\% & BBA & $90 \%$ & 65 & Yes \\
\hline $\begin{array}{l}\text { Bank Islam } \\
\text { Malaysia }\end{array}$ & $\begin{array}{l}\text { Baiti Home } \\
\text { Fin-i }\end{array}$ & BFR-2.1\% & BBA & $90 \%$ & 65 & Yes \\
\hline $\begin{array}{l}\text { Bank Muamalat } \\
\text { Malaysia }\end{array}$ & Home Fin.-i & BFR-2.2\% & BBA & $\begin{array}{l}100 \% \text { Incl. } \\
\text { Mort. Takaful }\end{array}$ & 70 & Yes \\
\hline $\begin{array}{l}\text { CIMB Islamic } \\
\text { Bank }\end{array}$ & Home Fin.-i & BFR-2.0\% & BBA & $95 \%$ & 70 & $\begin{array}{l}\text { Yes for Fin. less } \\
\text { than RM500k }\end{array}$ \\
\hline $\begin{array}{l}\text { Hong Leong } \\
\text { Islamic }\end{array}$ & $\begin{array}{l}\text { Flexi Prop. } \\
\text { Fin.-i }\end{array}$ & BFR-2.4\% & BBA & $90 \%$ & 65 & No \\
\hline Maybank Islamic & $\begin{array}{l}\text { a) Home Equity-i } \\
\text { b) Maxi Home-i }\end{array}$ & $\begin{array}{l}\text { BFR-2.0\% } \\
\text { BRF-2.0\% }\end{array}$ & $\begin{array}{l}\text { MMP } \\
\text { BBA }\end{array}$ & $\begin{array}{l}100 \% \text { Include } \\
\text { Mort. Takaful }\end{array}$ & 65 & No \\
\hline $\begin{array}{l}\text { Public Islamic } \\
\text { Bank }\end{array}$ & $\begin{array}{l}\text { ABBA Home } \\
\text { Fin.-i }\end{array}$ & BFR-2.2\% & BBA & $\begin{array}{l}100 \% \text { Include } \\
\text { Mort. Takaful }\end{array}$ & 70 & Yes \\
\hline $\begin{array}{l}\text { RHB Islamic } \\
\text { Bank }\end{array}$ & $\begin{array}{l}\text { Equity Home } \\
\text { Fin.-i }\end{array}$ & $\begin{array}{l}\text { Islamic Base } \\
\text { Rate- } 1.9 \%\end{array}$ & MMP & $95 \%$ & 65 & Yes \\
\hline
\end{tabular}

Table 5. Summary of Islamic Home Financing Package by Foreign Banks

\begin{tabular}{lllllll}
\hline Foreign bank & $\begin{array}{l}\text { Name of } \\
\text { Home Fin. }\end{array}$ & $\begin{array}{l}\text { Rate @ } \\
27.12 .11\end{array}$ & $\begin{array}{l}\text { Shariah } \\
\text { Concept }\end{array}$ & $\begin{array}{l}\text { Mar. of } \\
\text { Fin. }\end{array}$ & $\begin{array}{l}\text { Max } \\
\text { Age }\end{array}$ & $\begin{array}{l}\text { Lock in period and } \\
\text { early settle penalty }\end{array}$ \\
\hline $\begin{array}{l}\text { Al Rajhi Bank } \\
\text { Asian Finance Bank }\end{array}$ & Home Fin.-i & BFR-2.1\% & BBA & $90 \%$ & 65 & $\begin{array}{l}\text { Yes } \\
\text { (Min }\end{array}$ \\
$\begin{array}{l}\text { Home Fin.-i } \\
\text { HSBC Amant RM500K) }\end{array}$ & BFR-1.5\% & MMP & $90 \%$ & 65 & No \\
$\begin{array}{l}\text { Kuwait Finance House } \\
\begin{array}{l}\text { OCBC Al-Amin Bank } \\
\text { Standard Chartered Saadiq }\end{array}\end{array}$ & Home Smart-i & BFR-2.1\% & MMP & $85 \%$ & 65 & Yes \\
\hline
\end{tabular}

Table 4 and 5 show the summary of Islamic home financing package offered by both 10 local banks and 6 foreign banks. The rental rate, the name of banks' home financing package, what types of shariah concept home financing, the maximum margin and age of financing were included in the summary tables.

\subsection{Comparison of Home Financing Packages Between Local Islamic Banks}

From Table 4, it is observed that all the above local banks are also using base financing rate while RHB Islamic Bank name it differently as Islamic Base Rate (IBR) to calculate the rental rate. The base financing rate they are using for Islamic home financing are actually the same rate as base lending rate and they have not adhered to the MMP principle of using rental over price of property as rental rate.
The local banks have named their Islamic home financing package differently and the most common name is Home Financing-i. Most of the banks' home financing are based on BBA concept as BBA is first introduced in Malaysia Islamic banking than MMP. Furthermore, a lot of home owners do not understand what are the differences between BBA and MMP unless they study them.

Nevertheless, there is also exception whereby RHB Islamic Bank's home financing is based on MMP concept. On the other hand, Maybank Islamic is offering both BBA and MMP concept home financing with the same rental rate and margin of financing. Most of the rental rates the local banks offer are around BFR minus 2 to $2.2 \%$. The cheapest rental rate is offered by Hong Leong Islamic Bank at BFR minus 2.4\% and the most expensive rental rate is charged by RHB Islamic Bank at 
Islamic Base Rate minus 1.9\%. These means Hong Leong Islamic Bank is the most aggressive Islamic bank and RHB Islamic Bank is the least aggressive Islamic bank in securing home financing from the home owners.

On the margin of financing, most of the local banks are offering the maximum 90 to $95 \%$ financing from the current property value and there are also 3 banks offering $100 \%$ financing which includes the Mortgage Takaful. The 3 banks are Bank Muamalat Malaysia, Maybank Islamic and Public Islamic Bank.

While on the maximum limit of age the house owner can borrow, most local banks offer the home financing until the age of 65 to 70 years old and the exception goes to Affin Islamic Bank of which they can offer home financing up to the age of 75 years old.

According to MMP principles, Islamic banks supposed not to charge penalty if the home owners redeem their property by refinancing their home financing with another bank at any time. Most of the local Islamic banks are charging penalty rate of 2 to $3 \%$ from total amount of home financing and the lock in periods are ranging from 3 years to 5 years.

Nevertheless, there are also some Islamic banks adhered to MMP principle of not charging any early settlement fees. CIMB Islamic Bank only not imposes early settlement charges and lock in period if the home financing amount is RM500,000 and above. The local Islamic banks that do not impose any early settlement charges and lock in periods are only Maybank Islamic and Hong Leong Islamic Bank.

From the above comparison, it shows that Maybank Islamic and Hong Leong Islamic Bank are somehow adhered to MMP principles by not imposing any early settlement charges however they are still using the floating base financing rate which is based on the conventional base lending rate to calculate the rental rate.

\subsection{Comparison of Home Financing Packages between Foreign Banks}

From Table 5, it is observed that all the above foreign banks are also using base financing rate to calculate the rental rate. The base financing rate they are using for Islamic home financing are actually the same as conventional base lending rate, Therefore, they are also the same as local banks by not adhering to the MMP principle of using rental over price of property as rental rate.

Most of the foreign banks named their Islamic home financing package differently; only Asian Finance bank and Al Rajhi Bank use the most common name of Home
Financing-i. All the foreign banks' home financing are based on MMP concept except Asian Finance Bank's home financing is based on BBA concept. It shows that foreign Islamic banks are more up to date with the latest development in Islamic banking than local Islamic banks.

On the rental rate, most of the foreign Islamic banks are also offering the same as local Islamic banks at around BFR minus 1.9 to $2.1 \%$. The cheapest rental rate is offered by Standard Chartered Saadiq at BFR minus $2.3 \%$ and the most expensive rental rate is charged by Asian Finance Bank at BFR minus $1.5 \%$ only. According to the officer from Asian Finance Bank, their rate for home financing is not so competitive as their bank is focusing more on corporate and commercial financing.

On the margin of financing, most of the foreign banks are also offering the maximum 90 to $95 \%$ financing from the current property value. Only HSBC Amanah Malaysia is offering the lowest financing margin of $85 \%$ among all local and foreign Islamic banks, meaning they have tighten control on credit management than all other banks.

While on the maximum limit of age the house owner can borrow, most foreign banks offer the home financing until the age up to 65 years old and Kuwait Finance House offers slightly longer at the age of 70 years old.

In the case of early settlement of home financing by home owners, all foreign Islamic banks are also charging penalty rate of 2 to $3 \%$ from the total amount of home financing and the lock in periods are also ranging from 3 years to 5 years. Only Asian Finance Bank is not imposing any penalty on early settlement and there is also no lock in periods but the minimum home financing amount must be RM500,000 and above.

For comparison on foreign Islamic banks, it shows that only Asian Finance Bank is somehow adhered to MMP principles by not imposing any early settlement charges however they are imposing the minimum financing amount and also still using the floating base financing rate which is based on the conventional base lending rate to calculate the rental rate.

\section{CONCLUSION}

This study has attempted to compare a real case of Musharakah Mutanqisah Partnership contract from HSBS Amanah Malaysia's Diminishing Musyarakah Mutanaqisah HomeSmart-i facility for the financing of a property with what theory tells us. From our findings, it is revealed that in practice, HSBC Amanah Malaysia in this case is not practising MMP as it should be. One of the reasons is that instead of using the rental rate, it makes use of a base financing rate which is the same as 
base lending rate from the conventional financing system. This rate is also subject to fluctuations according to the Bank's discretion and depends on the market interest rate. The administration fees in this case is also borne by the customer which against the MMP theory because it is supposed to be a partnership contract with each party bearing risks, losses and profit according to the capital contribution. It was also found out that in the real case, the base financing rate is the same for property located anywhere unlike in a theoretical MMP where the rental rate depends on the location of the property.

In the case of customer's default, HSBC Amanah will exercise the power of attorney to sell the property to a third party and the bank will keep all the proceeds after deducting all the outstanding financing amount, rental arrears and liquidation cost which is contradicting with the MMP principles.

It can thus be concluded that HSBC Amanah Home Smart-i facility, the MMP in practice is moving towards a convergence to conventional banking and in fact, there is no difference with conventional housing loan. For HSBC Amanah to truly offer and reflect the principles and tenets behind MMP contracts, it has to make some amendments to the terms and conditions as stated in its offer letter for a diminishing musharakah mutanaqisah partnership contract.

Further research was carried out to find out the Islamic home financing package offered by other local and foreign Islamic banks at a more current date than the date of HSBC Amanah's Home Smart-i facility. The findings show that all other local and foreign banks are also using base financing rate instead of rental rate in calculating the house repayment per month.

Nevertheless, there are 3 Islamic banks, namely Maybank Islamic, Hong Leong Islamic Bank and Asian Finance Bank are not imposing any charges and lock in periods for early settlement and redemption. They have somehow adhered to the MMP principles of not imposing any additional charges.

\subsection{Limitation and Future Research}

This study is only carried out thorough research on one Islamic bank which is HSBC Amanah Malaysia Berhad and also touching the surface of home financing package offered by 10 local Islamic banks and 6 foreign Islamic banks, it might not able to represent the whole Islamic banking in Malaysia.

There are also other Islamic banks in Malaysia that are not included in the research. They are Al-Hidayah Investment Bank (Labuan), Alkhair International
Islamic Bank Malaysia (formerly known as Unicorn International Islamic Bank), Bank Kerjasama Rakyat Malaysia, Bank Persatuan Malaysia, PT Bank Muamalat Indonesia and RUSD Investment Bank (Labuan). All of the above banks are the members of Association of Islamic Banking Institutions Malaysia as at 23rd December 2011.

Therefore, it is suggested that more comprehensive research need to be done on all the Islamic banks in Malaysia including the offshore banking centre in Labuan.

It is also suggested that the research must be carried out based on offer letters by the Islamic banks concern and was not just based on the Islamic banks' website information on MMP as there are a lot of terms and conditions are stipulated in the offer letters.

The research on HSBC Amanah Malaysia was based on the MMP home financing offer letter dated 30th June 2010 and the research on other 10 local Islamic banks and 6 foreign Islamic banks were done on 27th December 2011, the findings were valid and truth around the research date. After the above date, the banks might have changed their policies on Islamic home financing in Malaysia. Therefore, it is suggested that future research need to be done again to analyze whether the banks are changing their policies to adhere to the MMP theory.

\section{REFERENCES}

Al-Harran, S.A.S., 1993. Musharakah Financing Concept, Principles and Financing. Institute for Policy Research, Malaysia.

Bendjilali, B. and T. Khan, 1995. Economics of diminishing musharakah. Islamic Research and Training Institute. Jeddah.

Haron, S., 1997. Islamic banking: Rules and regulations. Pelanduk Publications.

Meera, A.K.M. and D.A. Razak, 2005. Islamic home financing through musharakah mutanaqisah and albay bithaman ajil contracts: A comparative analysis. Rev. Islam. Econ., 9: 5-30.

Meera, A.K.M. and D.A. Razak, 2009. Home financing through the musharakah mutanaqisah contracts: Some practical issues. Islam. Econ., 22: 3-27.

Nor, N.M., 2008. Musharakah mutanaqisah as an Islamic financing alternative to BBA. Malaysian Islamic Finance Monthly, pp: 22.

Osmani, N.M. and M.F. Abdullah, 2010. Musharakah mutanaqisah home financing: A review of literatures and practices of Islamic banks in Malaysia. Int. Rev. Bus. Res., 6: 272-282. 
Lee Ching Lung / American Journal of Economics and Business Administration 5 (3): 95-106, 2013

Razak, D.A., 2006. BBA home financing: An analysis. National Seminar on BBA Home Financing. Islamic Banking and Finance Institute Malaysia.

Smolo, E., 2007. A Theoretical Comparison between alBay' Bithaman Ajil, Musharakah Mutanaqisah Partnership and Ijarah Sukuk. MSc Thesis, International Islamic University Malaysia.
Usmani, M.I.A., 2002. Meezan Bank’s guide to Islamic banking. Darul Ishaat.

Usmani, M.T., 2005. An introduction to Islamic finance. Maktab Ma'ariful Qur'an. 